- Charles H. P. Zuckerman

Department of Anthropology

University of Michigan

zuckermc@umich.edu

\title{
Phatic Violence? Gambling and the Arts of Distraction in Laos
}

\begin{abstract}
"Tempted," as he put it, by the "demon of terminological invention," Malinowski first coined the term "phatic" as one half of a two-word compound, "phatic communion." Since Malinowski, "phatic" has often been used to imply a semiotic equation where mere communicative contact automatically produces positive social relations among those communicating. This article explores a genre of "trash talk" on the pétanque gambling courts of Luang Prabang, Laos to challenge this assumption and clarify multiple senses of "phaticity." With close attention to talk used not for positive communion but for distraction, I argue that communicative contact as a technical phenomenon must be separated from communicative contact as a sign of other kinds of meaning. [Phatic, Laos, Interaction, Gambling]
\end{abstract}

"Since Thursday I have been in a state of utter distraction. I must absolutely stop this. It is caused by too violent and too passionate contact with people, by an unnecessary communion of souls." -Bronislaw Malinowski (1967:264), A Diary in the Strict Sense of the Term

$\mathrm{O}$ n the male-dominated pétanque courts of Luang Prabang, Laos, "saj jaa" is pervasive. ${ }^{1}$ Saj jaa literally means "to apply medicine" or "to dose," and, like a dose of medicine, saj jaa affects players' bodies and emotions, causing them to lose focus and play poorly. Similar to "trash talk" on a basketball court or "sledging" on a cricket field, "doses" are talk meant to distract. Doses during pétanque (a French game played like bocce and lawn bowling) can take many forms: a repeated offer to bet, a call to "smile" for the anthropologist's camera, or a scream, right in an opponent's face, just as he is about to release his pétanque ball. Upon receipt, doses spur both laughter and anger, and transform pétanque from a contest of mere physical prowess into a game of hearts, minds, and words.

Why do these men spend so much time talking, laughing, and fretting about dosing? What is at stake in their discussions about distraction? Below, I draw on interviews, filmed games of pétanque, and audio-recorded transcription sessions to show that "dosing" concerns, among other things, the meaning of communicative contact and the limits of semiotic autonomy during games with money on the line. While players in these games try to avoid talk, dosers try to foster it. In acts of dosing, dosers instrumentalize communicative contact. They prey on their victims' propensity to attend to what is addressed to them and exploit what we might call the grappling hooks of communication-loud noises, directed gaze, sensorially engaging movements, questions, and other canonical "first pair parts" — to ensure involvement.

Journal of Linguistic Anthropology, Vol. 26, Issue 3, pp. 294-314, ISSN 1055-1360, EISSN 1548-1395. Copyright (C) 2016 American Anthropological Association. DOI: 10.1111/jola.12137. 
On first look, nothing about dosing may seem especially surprising. Relatively antagonistic distractions in sports are familiar (e.g., Quealy and Wolfers 2015), as are "cat-calls," DDoS attacks, Internet "trolls," and other forms of contact that violate rather than build "positive" social relations. Yet, while such examples are recognizable and commonplace, anthropologists, sociolinguists, and those studying communication nevertheless often assume communicative contact is inherently good, as if it could in and of itself create positive bonds among communicants. This assumption is clear in how scholars discuss the notion of "phaticity." Although phaticity has recently become a productive topic for reflection (e.g., Elyachar 2010; Lemon 2013; Nozawa 2013; Slotta 2015), the term itself contains and invites the conflation of two distinct senses: a "communion" sense and a "contact" sense. To avoid confusion we should excise phaticity's communion sense. Only after we analytically separate communicative contact as a technical phenomenon ("contact phaticity") from communicative contact as a sign of other kinds of meaning and pragmatic function can we understand the variety of ways actors make contact meaningful.

In the second half of this paper, I return to the pétanque court. I show that in doses and discussions about dosing, people talk about, and at times respond to, communicative contact as a sign not of communion, but distraction. In these discussions, the court is imagined as a space of relative communicative paranoia where almost any contact might be suspect and where dosers try to entice players into listening against their will. Dosers do not engage in "phatic communion" - i.e., communion achieved through mere communicative contact - but, instead, they wield and deploy what we might call, a bit hyperbolically and with an aim toward contrast, phatic violence. While players are at times tempted to respond to this "violence" with argument, anger, and outrage, they prove themselves and the quality of their characters insofar as they can ignore it, keep "cool," and maintain semiotic autonomy in the face of distraction.

\section{Contact Tropes and the Two Phaticities}

Malinowski, "tempted," as he put it, by the "demon of terminological invention," first coined "phatic" as one half of a two-word compound, "phatic communion." ${ }^{2}$ "Phatic communion," he wrote, captured "a new type of linguistic use," "a type of speech in which ties of union are created by a mere exchange of words" (Ogden et al. 1946:315). Silence, Malinowski argued, is "alarming and dangerous" but "[t]he breaking of silence, the communion of words is the first act to establish links of fellowship, which is consummated only by the breaking of bread and the communion of food" (Ogden et al. 1946:314; see also Hayakawa 1941:80).

Malinowski's first descriptions of phatic communion imply a semiotic equation in which mere chatter, mere linguistic contact, produces positive rapport. ${ }^{3}$ I argue that this equation is neither automatic nor pre-semiotic but a contact trope, an "ethno"-assumption where the fact of communicative contact (or its absence) is itself thematized, reflected on, and - at what we might think of as a higher "order of indexicality" (Silverstein 2003) - made into a sign of something else. Contact tropes are condensations of semiotic ideologies, and when one starts looking for them, one finds them almost everywhere. In a bar, for instance, when patrons mention a bartender's communicative "availability" - the ease with which a patron can attract her attention - as a sign of good service: "She's very attentive." Or in the New York City subway, where eye contact is alternately a way to find a date and, "if it's a 'crazy' New Yorker...an invitation to their crazy" (Buckley 2015).

Contact tropes abound. But the trope Malinowski identified and adopted with the notion of "phatic communion"-that contact creates positive fellowship - seems especially entrenched both in common parlance (e.g., "We text all the time" or "She never calls") and in academic discussion. For example, consider Durkheim's (1915) notion of "collective effervescence" - a moral force outside ourselves, the result of 
mere interaction - or consider Sapir (1949:16), who wrote of an "important sense in which language is a socializer beyond its literal use as a means of communication." "This," Sapir continued, "is in the establishment of rapport between the members of a physical group, such as a house party. It is not what is said that matters so much as that something is said.... This caressing or reassuring quality of speech in general, even where no one has anything of moment to communicate, reminds us how much more language is than a mere technique of communication." 4

At first blush, greetings have seemed especially compelling proof of the inseparability of contact from communion. Greetings seem to combine the moment of contact with pleasant, "communion producing" turns of phrase, "easing" the transition into and out of interaction (see Laver 1975:236). But even greetings provide flawed evidence. As Duranti $(1992: 668 ; 1997)$ notes, a formal greeting need not overlap with the moment of establishing communicative contact (that is, a greeting is not always a "summons" nor an "answer" (Schegloff 1968)). But more importantly, not all greetings, broadly understood, build a "good" relationship: think of an aggressive "Hello!" on a sidewalk or a shouted "Hey baby!" from a moving car. These utterances are more likely to leave one frazzled and shaken-up than communed.

Such counter-examples of contact without communion appear obvious when mentioned. Much like we know that disputes, arguments, and physical violence exist and are linguistically mediated (e.g., Brenneis 1988; Pagliai 2010), so too do we easily recognize that communicative contact is often aggressive, unwanted, or unremarkable. Nevertheless, the assumption that contact creates communion continues. To parallel Irvine's (1996:123) commentary on popular assumptions about language and community, just as it has often seemed "'natural' to suppose that [a shared] language itself creates community," so too has it often seemed "natural" that merely being "in touch" or "in contact" creates positive bonds among communicants.

For linguistic anthropologists, the assumption is buried in our chief analytic for studying contact: phaticity. ${ }^{5}$ Phaticity has two prominent and distinct senses. On the one hand, phaticity is used in a communion sense, where it refers to semantically "empty" talk that builds positive social relations, such as casual talk about the weather. On the other hand, phaticity is used in a contact sense, where it refers to communication that is itself about or oriented toward communicative contact, such as, "John!", said as a summons. While the communion sense is concerned with producing "positive" interactional effects through language, the contact sense is a technical category meant to describe an orientation to contact generally, no matter the (dis)affiliative effects of contact. When phaticity's two distinct senses are conflated, when the term is used in both its senses at the same time, it carries forward the assumption that contact creates communion.

The "communion sense" of phaticity has not received much sustained attention by linguistic anthropologists. Yet, across fields, use of the "communion sense" is more pervasive than use of the "contact sense," especially among sociolinguists and those studying pragmatics. This sense can also be found in related disciplines (e.g., communication studies: Wang, Tucker, and Rihll 2011; Wang, Tucker, and Haines 2012), in popular, educated discourse, and even in my computer's built-in dictionary. Since Malinowski's invention of "phatic communion," the communion sense of phaticity has been relatively stable, continuing to refer to language with (1) a "nonreferential character" and (2) an "emphasis on social ties" (Meltzer and Musolf 2003:143). Those studying this sense recently and in depth (e.g., Coupland 2014; Coupland, Coupland, and Robinson 1992; Laver 1975; Meltzer and Musolf 2003; Schneider 1988; Senft 1995; Trudgill 2003:102-103) however, tend not to care much about the notion of "communicative contact." Instead, these scholars seem most interested in a question long at the core of every variety of "socio"-linguistics broadly understood: to what extent is talk socially oriented? Simply put, an argument for communion phaticity is an argument that semantico-referential 
meaning is not the only "meaning" at stake (e.g., Silverstein 1976). This is a battle Malinowski waged on other fronts as well (Ogden et al. 1946; Malinowski 1965; for Malinowski's approach to language generally, see Firth 1957; Young 2012), and one that linguistic anthropologists wage frequently, albeit with terms other than "phaticity." 6

In contrast to the communion sense of phaticity and its focus on positive social affiliation, the contact sense of phaticity captures communication that is oriented to the preconditions of communicative contact. Jakobson, who borrowed the term "phatic" from Malinowski, ${ }^{7}$ was the first to develop the notion. He introduced the "phatic function" as one of six functions of language. He defined it as an orientation to "contact," or the "physical channel and psychological connection between the addresser and the addressee, [that enables] both of them to enter and stay in communication" (1960:353).

In his enormous oeuvre, Jakobson (1960:355-356) touches on the phatic function only briefly:

There are messages primarily serving to establish, to prolong, or to discontinue communication, to check whether the channel works ("Hello, do you hear me?"), to attract the attention of the interlocutor or to confirm his continued attention ("Are you listening?" or in Shakespearean diction, "Lend me your ears!"- and on the other end of the wire "Umhum!"). This set for CONTACT, or in Malinowski's terms PHATIC function, may be displayed by a profuse exchange of ritualized formulas, by entire dialogues with the mere purport of prolonging communication. Dorothy Parker caught eloquent examples: “'Well!' the young man said. 'Well!' she said. 'Well, here we are,' he said. 'Here we are,' she said, 'Aren't we?' 'I should say we were,' he said, 'Eeyop! Here we are,' she said, 'Aren't we?' 'I should say we were,' he said, 'Eeyop! Here we are.' 'Well!' she said. 'Well!' he said, 'well.'” The endeavor to start and sustain communication is typical of talking birds; thus the phatic function of language is the only one they share with human beings. It is also the first verbal function acquired by infants; they are prone to communicate before being able to send or receive informative communication.

In this passage, Jakobson seems to have a primarily technical view of the communication problem in mind, like that evident in the work of Claude Shannon (see Geoghegan (2011) and Jakobson (1961) for Jakobson's view of "Information Theory"). Like Shannon's (1998:31) theory of communication, Jakobson appears mostly concerned with the "engineering problem" of language, although he mentions some tropic uses of contact in his definition.

But what exactly this "engineering problem" entails is not especially clear, nor has it been the subject of much exegesis. One starting point is Clark's (1996:152) discussion of a number of "levels" in communicative acts. ${ }^{8}$ The lowest and most basic of these levels concerns the management of contact. Clark calls this level the level of "execution and attention" and it involves the executing of a sign for someone (i.e., addressivity or "targeting" (Bales et al. 1951:462)) and the attending to a sign from someone (i.e., attention). Think of leaning in so a friend can hear you in a crowded bar or staring at your computer to hint at a chatty study mate to quiet down; "engineering" signs like these affect - that is, enable or impedecommunicative contact and presuppose what that contact might require. When one starts exploring these signs closely, it becomes clear that the notion of "contact phaticity" still bundles together multiple elements worth distinguishing: procontact versus isolationist signs; the different semiotic modalities and technologies people use to act on contact; gradient degrees of contact; and the extent to which contact is symmetrically or asymmetrically oriented to by participants, for example. ${ }^{9}$

While still inchoate, a technical view of phaticity like this is helpful because it emphasizes that contact's pragmatic effects are underspecified. Focusing on execution and attention also helps avoid the notion of "channel" in favor of "contact." Channels bring to mind relatively permanent and discrete things, as if, once 
established, they sit like a tunnel from the UK to France. But "communicative channels" are not always already "there." ${ }^{10}$ Instead, they are often produced and maintained through constant semiotic (i.e., not strictly "linguistic"11) work: "backchannel" cues (Saft 2007), shifts in gaze (Goodwin 1981), adjustments in bodily orientation (Schegloff 1998), and so on. ${ }^{12}$ As Sidnell (2009:132) puts it, once we take note of the abundance of "non-linguistic" forms, we see "that contact is a pervasive concern and a contingent accomplishment which is achieved moment-by-moment in the details of interaction."

No matter how exactly we delimit what contact is, it is clear that questions of contact are analytically distinct from the communion sense of phaticity. While the communion sense captures language aimed at fostering positive sociality, contact phaticity captures language aimed at acting on, or commenting upon, the preconditions of communication. And yet, even in linguistic anthropology where the communion sense is not subject to much discussion (and perhaps because it is not subject to much discussion), communion phaticity haunts our notion of contact. The two senses are often combined, and the communion sense is assumed to go along with, or emerge from, contact. In Ahearn's (2011:19-20) recent summary of Jakobson's functions, for example, she writes that the phatic function is prominent in both a sound test, where the focus is "mainly on the physical channel or mode of contact (a microphone)...." and, "[w]hen the channel is a more abstractly conceived social connection rather than a physical one - a relationship of friendship or kinship, for example...." Kunreuther (2010:340) similarly argues that when FM radio callers "pepper their conversations with radio hosts with questions like 'do you hear me?' or 'did you get my letter?' or the common Nepali greeting 'Have you eaten rice?'," they draw ". . .attention to the voice and the radio as mediating tools of social relations." While both Ahearn and Kunreuther would surely agree that mere contact does not produce communion, the term phaticity-with its dual senses-smuggles the opposite assumption forward.

Over the last few years, as interest in "phaticity" has increased, multiple anthropologists have identified contact tropes like Malinowski's "phatic communion" in their fieldsites. Slotta (2015), for example, analyzes truth and reconciliation hearings in Canada as "phatic rituals," which "aim to establish a form of communicative contact - a kind of phatic communion-among citizens and agents of the state that realizes liberal and democratic ideals of communication" (2015:131; internal citation removed). He shows that support for truth and reconciliation hearings is based on a contact trope qua Habermasian ideal: an "open," "equal," and "free" state of communicative contact (2015:135) where contact will automatically yield positive political consequences. Nozawa describes how Japanese organizations mobilize varieties of contact to counteract kodokushi or "solitary death," especially among the elderly (2015:283-284). For example, one group organizes a service called Fureai Yübin, or "touching together postal services", hand-delivering letters to the elderly and telling the recipients "Hello, you've got mail." For this group, the goal is contact itself, as contact is represented as a means for fostering positive sociality, "a society of touching-together" (fureai shakai). Finally, Elyachar (2010) argues that Cairene women use "phatic labor" to create an infrastructure of "communicative channels." She contends these women spend time visiting others often for no purpose other than "just being sociable" and that anthropologists should attend to this phatic labor, even when it is not ostensibly economic.

Elyachar's argument, in particular, is worth unpacking. While she argues persuasively for the importance of neglected modalities of sociality, she at times treats social relations as automatically following from, or consisting of, "communicative channels." Surely there is much more to the social relations she describes than just regular contact or keeping the channel "open." Perhaps people in Cairo tend to grade or consider social relations in terms of the frequency or length of social visits? Or perhaps, like Elyachar herself does in the article, they discuss the quality of "knowing" other people as if it were a "communicative channel"? While contact 
might be a precondition for some social relations to exist, it is not the substance or a necessary and sufficient feature of these relations - even if it is imagined as such. The details and ethnographic specificities of contact matter, they are the infrastructure that makes contact meaningful, and these same details are liable to be forgotten or ignored when academics borrow the notion of "phatic communion" and apply it to new social and semiotic contexts.

Lemon (2013:69) argues that not all "communicative gaps" are the same, that there is "no single, universal experience of 'downed wires' or 'tuning in' to radio static..." Rather, and following Keane (2014:11), the technical dimensions of such communicative gaps, and communicative contact generally, are affordances for social and ethical meaning. It is an oft-repeated truism in linguistic anthropology that the poetic function need not be limited to "poetry," or confined to a single pragmatic effect. To make "phaticity" more useful, we should be equally adamant that positive communion is not embedded "inside" contact (see Fleming and Lempert 2014 for recent discussion of poetic performativity), even if it is often interpreted and talked about as such in our fieldsites. Contact qua affordance motivates rather than determines contact tropes and construals of communication in interaction.

To make this point starkly, I now introduce phatic communion's foil, phatic violence.

\section{Contact Is Distraction}

Tom, a man in his mid-forties whose in-laws own a pétanque court in Luang Prabang, had just come back from a month-long trip to Laos's capital, Vientiane. In the capital, he had gone to a funeral, briefly ordained as a novice monk, and, when unoccupied, driven from one pétanque court to another, gambling for money with other men. When he returned, a few of us drank beer at his in-laws' court, and he told us what it was like to gamble in the capital. People play for much more money than in Luang Prabang, he told us, and they play "politely" (suphaap4). They are not loud, and they never dose.

Everyone listening at the court seemed unsurprised. Like his listing of the large amounts of money for which the men in Vientiane played, his mentioning of the frequency with which the gamblers changed courts to balance matches, and his stressing that even some of the best players in Luang Prabang would not have the "heart" to play in Vientiane, his observations seemed to confirm people's assumptions about how big time gambling games work and feel. When money is on the line, too much talk-and especially anything resembling a dose-is liable to lead to argument, and thus best avoided. In these games where dosing (and the search for any advantage generally) is most desirable for the doser and vigilantly anticipated by his victim, dosing is also most sanctioned. As one man told me in an interview, most players in big money games, fearing violence and anger, "do not even dare open their mouths."

Ideologies around "talk" and "dosing" during money gambling games provide a stark contrast to assumptions that contact creates communion. While games in Luang Prabang are rarely silent, and serious violence is rare, communicative contact on the court is sometimes fraught with tension and conflict. In this section, I trace the economic inflection of dosing as an ethno-metapragmatic category, the tendency to frame doses as "just talk," and the disjuncture between typical doses on the court, on the one hand, and prototypical doses, on the other. While the former typical doses use contact as scaffolding for distraction, the latter doses distract through contact, signals that grab attention, and anchor the contact trope at the heart of dosing: contact is distraction.

Over the past 15 years, pétanque has become extremely popular in Laos. The French form of boules (like bocce, bowls, and lawn bowling), first invented in the early 1900s, can now be seen in almost every nook and cranny of Luang Prabang, the city where I conducted the majority of my fieldwork. Pétanque in Luang Prabang typically involves gambling in one of two ways: either for beer or for money. People tend to 
talk about the two kinds of gambling in maximally contrastive ways, claiming that beer-gambling builds solidarity, friendship, and love among the players, and that money-gambling is likely to cause arguments and social discord. These two styles of play are ideal typical categories, and their relationship to actual economic practice, to the contexts in which they are most mentioned, and to types of characterological figures, go beyond the scope of this article. But suffice it to note that while people do frequently distract one another and sometimes accuse one another of dosing in beergambling games, dosing is closely associated with games where pure cash is on the line, even though it is most sanctioned within these games. Dosing has connotations of greedy and antagonistic interest in both winning the game and winning money. Money gambling games in Luang Prabang are thus, by assumption, more serious games than beer-gambling games, where a dose is both less tolerated and expected, and where the play-frame and the "fun" (muan1) of the event is liable to break (cf. Bateson 1972:182). The examples of dosing below are taken from two moneygambling games played on two different courts in the city. Both games had audiences of over a dozen, some of whom were betting. ${ }^{13}$ For reasons again too elaborate to explore here (e.g., the gendered nature of economic risk and the public-ness of pétanque), these more serious money gambling games are almost exclusively played by adult men.

Partly because of dosing's association with greed, dosing is something with which players try not to be publicly associated. Alleged dosers invariably insist they are "merely talking" or "just joking" (e.g., vaw4 laa5 laa5; vaw4 sùù1 sùù1; vaw4 liin5; vaw4 jòok5). ${ }^{14}$ Sometimes in interviews and casual conversations, when I asked people to tell me about dosing, they claimed they knew nothing about it and laughingly pointed me to others: "You want to know about dosing," one man said during an interview at the court, "ask Bii over there! He has seven techniques!" In contrast to acts like agreeing to play a game in the first place or ordering an M150 energy drink from a drink seller at the court, doses are rarely "on record." Rather, they tend to function as "indirect performatives" (Lempert 2012), plausibly deniable and publicly suspended between being "just talk" (kaanvaw4) and "distraction" (kaanlopkuan3 samaathiq1). A claim on the court that a dose is a dose is thus not merely descriptive but also, political, and usually responded to with a denial.

Take, for example, Can's response to an accusation of dosing during a filmed money gambling game (Figure 1, below). In the game, a man named Bii and I are playing as teammates against PhomPhui. We are playing for about twenty dollars and have an audience of around a dozen, including Can. Can is a small-in-stature, large-in-personality boat captain in his mid-forties who often gambled away the slow days when he did not have customers. Can bet twenty thousand Kiip, (about two dollars and fifty cents; a small bet for the court), that Bii and I would lose. Shortly after Can made his bet, and just as Bii readied to take a shot, Can called out, khaam5 hua3 or, "[you'll] overthrow [the ball]," a common dose. Bii, apparently unfazed, successfully made his shot.

This sequence highlights many of the regular features of dosing and its interpretation: Can (presumably) aims to influence the game by telling Bii he will "overthrow the ball" (line 1); Can denies he is dosing (line 7); and finally, another spectator explicitly ties Can's dosing to the fact that he is gambling on the game (line 8), which he also denies (line 10).

What is phatic about Can's dose? "You'll overthrow the ball" - like all talkrequires a threshold of contact to work, that is, it has to be both perceptible and perceived. But contact phaticity is not its most foregrounded function. Can aims to ensure that the dose is perceived by addressing it to Bii and as Can talks, he directly faces Bii. But once he delivers this line, he then turns away from Bii to watch Bii's ball hit its target. Can does not turn back toward Bii until more than five seconds later, when Bii accuses him of dosing. But while "You'll overthrow the ball" requires minimal contact to work, the common dose is designed to distract not merely through this contact, but through its content. One player explained how the phrase 


\begin{tabular}{|c|c|c|c|c|}
\hline LINE & SPKR. & UTTERANCE / TURN & RESSIVITY & COMMENTS \\
\hline 1 & Can & $\begin{array}{l}\text { khaam5 hua3 } \\
\text { cross head } \\
\text { "[You'Il] ovethrow [the ball]" }\end{array}$ & To Bii & $\begin{array}{l}\text { Can sits on bench, looking } \\
\text { toward Bii; Bii grips pétanque ball } \\
\text { in position to take shot, staring ahead. }\end{array}$ \\
\hline 2 & & [TAKES SHOT] & & $\begin{array}{l}\text { After two seconds Bii takes and } \\
\text { makes a shot, Can turns his head } \\
\text { toward the target ball. }\end{array}$ \\
\hline 3 & $\mathrm{Bii}$ & $\begin{array}{l}\text { khaam5 bòø-khaam5 kaø- beng1 nii4 naa1 } \\
\text { cross NEG-cross T.LNK watch DEM FAC } \\
\text { "Overthrown or not, look at this!" }\end{array}$ & To Can & $\begin{array}{l}\text { Bii takes a few steps and appears to } \\
\text { look toward Can's turned-away head. }\end{array}$ \\
\hline 4 & Bii & $\begin{array}{l}\text { bak2 Can khaam } 5 \text { bòø-khaam } 5 \text { kaø- beng1 nii4 naa } 1 \\
\text { M.bare Can cross NEG-cross T.LNK watch DEM FAC } \\
\text { "Can, overthrown or not, look at this!" }\end{array}$ & To Can & $\begin{array}{l}\text { Bii turns around and high-fives } \\
\text { Zuckerman and smiles. Can continues } \\
\text { facing away. }\end{array}$ \\
\hline 5 & $\mathrm{Bii}$ & $\begin{array}{l}\text { bak2 Can saj1 jaa3 haw2 qaq1 beng1 nii4 saalii2 } \\
\text { M.bare Can dose 1st.Sg Q.PLR watch DEM Zuckermar } \\
\text { "Can dosed me, look at this [Zuckerman]" }\end{array}$ & To Zuck. & $\begin{array}{l}\text { Bii points at Can twice: once at the } \\
\text { beggining of utterance, and once at } \\
\text { the end. Can continues facing away. }\end{array}$ \\
\hline 6 & Zuck. & $\begin{array}{l}\text { mêên 1 qaq1 } \\
\text { COP Q.PLR } \\
\text { "Yeah?" }\end{array}$ & To Can & Can continues facing away. \\
\hline 7 & Can & $\begin{array}{l}\text { bòø-daj4 saj1 naa1 kaø- vaw4 sùù } 1 \text { sùù1 } \\
\text { NEG-COMP dose FAC T.LNK speak just } \\
\text { "[I] didn't dose... I was just talking." }\end{array}$ & To Bii & Can turns toward Bii and speaks. \\
\hline 8 & Spec. & $\begin{array}{l}\text { liin5 saaw2 phan2 duu1 } \\
\text { play twenty thousand FAC } \\
\text { "He's playing for } 20,000 \text { [Kip], you know" }\end{array}$ & To Bii & $\begin{array}{l}\text { Spectator says this, looking to } \\
\text { Bii; Can smiles. }\end{array}$ \\
\hline 9 & Bii & $\begin{array}{l}\text { saaw2 phan2 naq1 } \\
\text { twenty thousand Q.PLR } \\
\text { "[You're] playing for twenty thousand?" }\end{array}$ & $\begin{array}{l}\text { To Can } \\
\text { (possibly) }\end{array}$ & Bii nods his head as he asks \\
\hline 10 & Can & $\begin{array}{l}\text { bòò1 naa1 } \\
\text { NEG FAC } \\
\text { "Nooo" }\end{array}$ & To Bii & $\begin{array}{l}\text { Can stops smiling and shakes his } \\
\text { head from left to right. He then smiles } \\
\text { again, and shakes his head once more } \\
\text { as Bii begins his next turn of talk. }\end{array}$ \\
\hline
\end{tabular}

Figure 1. You'll overthrow the ball.

should function: "if you tell someone he is going to overthrow [the ball]," he said, "[he might overthrow it], but he also might underthrow [it]." In other words, saying "you'll overthrow the ball" leads the addressee to make adjustments, attend to his throwing form, and to at least overthink his shot, even if he doesn't overthrow it.

In contrast to "You'll overthrow the ball," take Can's scream, occurring later in the same game. As Bii wound up to take a shot, Can, who was standing near him and previously silent, raised his hands and yelled. All three people with whom I tried to transcribe the scream gave different accounts of what Can actually said, but each of them stressed that the content of what he said did not matter. ${ }^{15}$ Bii missed his shot.

After the scream, Can scampered back to his seat and Bii told me to hit him "on the lips" with the pétanque ball I was holding. "Hit Bii on the lips," Can called back. "He is the one talking." "On the lips" (sop2), they both said, as if to target their respective weapons of phatic violence.

Unlike "You'll overthrow the ball," Can's scream used almost pure communicative contact to achieve his ends. Apparently, it succeeded. The scream worked through surprise, and, as one spectator put it immediately after it happened, the scream's effect was irresistible: "[Of course Bii] was surprised," the spectator said, "[Can] shouted so loud, [who wouldn't] be?"16 The scream was taken as a sign capable of forcing its interpretant - a sort of automatic phatic, the aural equivalent of what Virilio (1994:14) refers to as a "phatic image," a "targeted image that forces you to look and holds your attention."

While most doses do not distract like this, doses like the scream-with their timing, speed, volume, relative non-referentiality, and direct addressivity-seem to ideologically anchor what dosing "really" is. These doses are aimed almost entirely at initiating contact (of an immediate and brief variety) and engaging attention, and, in 


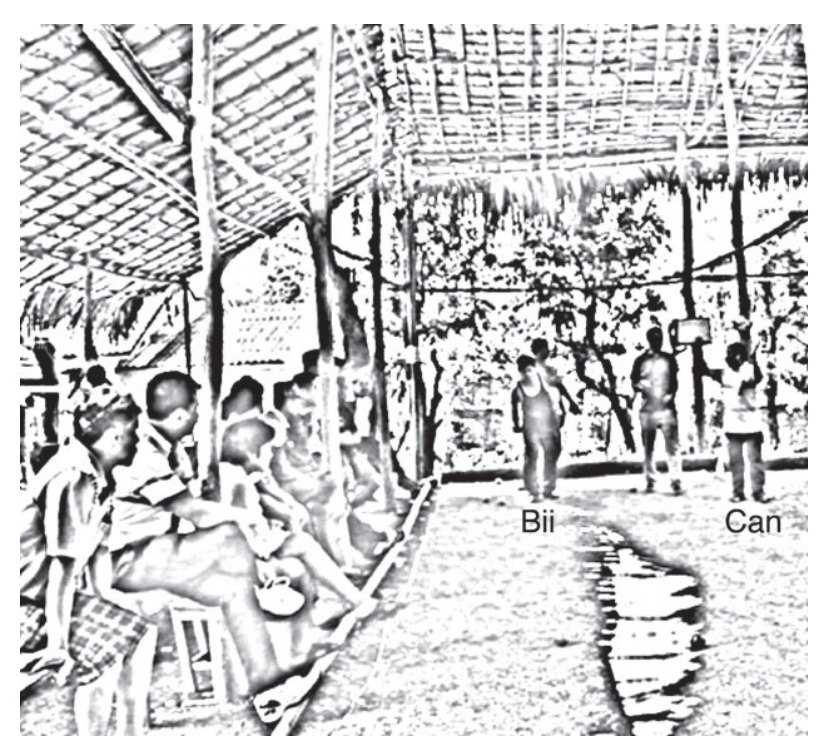

Figure 1a. Can's Scream

doing so they bolster the contact trope at the heart of dosing, where talk, not just screams, is shorthand for distraction.

Can's scream was not the typical dose one sees during money gambling games but it was prototypical. When I showed the video of Can's scream to Muu-a pétanque player, friend, and occasional research assistant-during a transcription session, he drew a strong line between such prototypical doses and normal doses. I paired the video of the scream with a video of a less forceful (possible) dose that Bii had made during the same game. In Bii's dose he had said, with characteristic acerbic wit, that his opponent PhomPhui was so overweight that his paunch prevented him from throwing the pétanque ball correctly. After the dose, PhomPhui, having just taken a shot in the game, briefly glanced at Bii as Bii talked about his belly and then quietly turned around to face the empty back-end of the court.

Sitting in front of a monitor in my room in Luang Prabang set up for the purpose, I asked Muu about Bii's comment: "Was he dosing?" Muu said that while one could argue that Bii was dosing, he would probably say Bii was merely "joking" (jòok5) or maybe "bothering" (kuan3). In other words, he was not obviously dosing, nor, Muu told me, was he saying anything worth being upset over (bòø-pèn3-taa3 khiat5). I then played Can's scream for Muu and he enthusiastically told me that it was "real dosing": "Yeah, this, this is real dosing," he said, "this one [is dosing]."17 Muu continued: whereas in Bii's joke one would need to ask Bii whether he was trying to dose to know for sure, in the case of Can's scream, it was "clear that [Can] was intending to dose." ${ }^{18}$ It was worth being upset over.

As Muu and a number of other players with whom I spoke put it, Can's scream was a paradigmatic forceful dose, a paragon of "real dosing" or what people sometimes call saj1 jaa3 puk2, or, "harsh, powerful dosing." The scream was in fact so powerful, so puk2, that Bii treated it as crossing the line between fair and foul play. After telling me to hit Can in the lips, Bii yelled at Can for screaming, for being an idiot, for not having the sense to see that this was a game with money riding on it. "Just talking is fine, but you can't go 'hoo' like that," Bii said, using the soundsymbolic "hoo" to mimic Can's more or less referentially empty scream, thereby drawing a line between "noise" and "talk."

The dispute between Can and Bii continued through a few more turns in the game following the scream. After much back and forth, Can framed Bii's sensitivity to talk as extreme: if Bii wanted him to be quiet, he would be completely quiet. This implied 
Bii was incapable of handling any talk or noise generally, not just screams. Rather than present himself as such a person, Bii invited Can not to shush up, but to do the opposite. After hitting his next shot Bii called out to Can, "You want to talk, you can talk all day!"19

Bii's reaction highlights another dimension of dosing on the pétanque court: staying "cool" in the face of talk is both valuable and valued. Resisting other's attempts to involve you communicatively is an instrument of winning money and respect, and an index and affirmation of the kind of person you are: here, a strong, autonomous man, inured to the pressure of others. When Can and other dosers claim they are "just talking," they are not only maintaining plausible deniability and anticipating accusations of greed, but challenging their potential victims to accept these doses as "just talk," to treat them as harmless, and thus prove that they are the kinds of people that can handle such talk.

Dosing is said to be partially conquerable through the development of an internally focused, masculine, and autonomous disposition that remains calm under both phatic and economic pressure. As one player bragged about himself, "No, [I never respond to hecklers]. [When I play], I'm not interested [in dosing]. That's me. I pay attention to [the shots I take] and that's it. I'm not interested in anything [else]." Much like I was told at the Buddhist temple down the road from the moneygambling court that a monk who meditates can learn to not be bothered, or even bitten, by mosquitoes if he meditates properly, pétanque players told me that they could become inured to the siren song of saj jaa.

Players tend to discuss this inurement in terms of the management of emotional states, often drawing analogies between experienced players and experienced fighting cocks (cf. Geertz 1973). Those most vulnerable to dosing are said to be "weak-hearted" (caj3 qòon1). Like "spring chickens" (kaj3 qòon1) with "soft, porous skin" (nang3 pùaj1), they "tremble" (san1 kathùan2) in response to dosing, and feel "angry" (caj3 haaj4) and "rushed" (caj3 hòn4, literally, "hot hearted"). Those who can resist dosing are tough and inured like "experienced fighting cocks" (kaj1 kêê1) with "tight, rubbery skin" (nang1 niaw3). Their hearts are stronger and more capable (caj3 khaw2 daj4). They stay "cool and calm" (caj3 jèn3, literally, "cool hearted") under "pressure" (khwaam2 kot2 dan3), and thus can play their best. ${ }^{20}$

A capable and brave heart allows one to treat dosing as just frivolous talk and to ignore it accordingly. The contact trope here is that contact is distraction, and the often-stated ideal is not to stop everyone else from talking, but to adopt a policy of ostensive phatic isolationism. Of course, in practice, players do communicate with others as they play. Not only do they perceive and at times directly respond to dosers as, for example, Bii responded to Can above, but they also often talk with and nonverbally signal to their opponents concerning issues required to facilitate the game: events happening around the court, bets to be made, and so on. In a basic way, playing the game requires communication. For instance, players must keep and communicate the score (often with scoreboards) and mark off the spot they and their opponents will throw from (with foot-drawn semi-circles on the gravel court).

And yet, while contact is unavoidable, the contact trope that one should not "attend to" or "be interested in" one's opponents continues. Tellingly, some of the most common forms of response to doses still explicitly deny a degree of communicative contact, even as they presuppose it. By far the most idiomatic response to dosing is to yell vaw4 nam 2 phaj3 - meaning, "who are you talking to?"to the doser. Players often shout this as their pétanque balls fly through the air, a challenge to whoever was talking. This phrase simultaneously denies the effective addressivity of a dose, as it also evokes the sense of a mismatch between the doser's intent and the strong, "cool-ness" of his target. Think here of Robert De Niro's character in Taxi Driver who follows his famous line, Are "you talking to me?" with, "Who the fuck do you think you're talking to?"

When players themselves become dosers, they are said to risk over-involvement. Talking, not just listening, can be dangerous for one's focus. This is what one 
audience member said happened, for instance, during the game I discuss in examples below: a player named Phuumii "tried to dose [his opponents], and ended up startling himself." Partly because of this risk of over-involvement, audience members betting on the game, not players, are said to be the most common dosers. When not dosing, these audience members also sometimes work to calm players they are supporting or betting on: "Cool your heart down," (caj3 jènjèn2) "Don't pay attention to anyone," (bòø-tòng 4 son3 caj3 phaj3 leej2 naa1) "Don't listen to what they say," (bòøtòng4 fang2 khwaam2 khaw2). Like vaw4 nam2 phaj3, some of these suggestions involve partial contradictions. When audience members tell players, for instance, to "not pay attention to anyone!" and then continue to offer further advice, they are producing messages that will only be received if their addressees are, in fact, paying attention. These kinds of comments reveal the inevitable chasm between ideologically dominant contact tropes-like the trope that communication is distraction, best avoided - and the realities of the cross-modal negotiation of contact phaticity.

\section{The Arts of Distraction}

Up to this point, I have discussed ideologies of how dosing qua metapragmatic category works and the contact trope that informs it. In this section, I explore two more examples of actual, filmed doses to show some of the ways dosers do in fact try to secure contact. These examples do not exhaust the methods dosers use to attract victims, which can vary endlessly from subtle comments, to screaming, to an audience member I once saw who placed a pebble in a player's exposed butt-crack. Rather, the examples show two methods with which one doser-in this case, a player named Phuumii - exploits the basic phatic resources we have as humans to invite communicative involvement for relatively antagonistic purposes. In both cases, Phuumii appears to establish contact as an attempt to distract his opponent and win the opponent's money. In both cases he ultimately fails, as his opponent almost entirely ignores Phuumii and continues to win the game.

The examples are from a money-gambling game that Phuumii played with three others: his partner, Saj, Taa and Taa's partner Laa. The first example showcases how Phuumii uses what conversation analysts call "First Pair Parts" (FPPs), like questions and offers to bet. These phatic "hooks" and, perhaps more accurately, the features that compose them (c.f. Stivers and Rossano 2010), invite both their target's attention and a verbal response, like an answer to a question.

The players were playing during the late morning at Luang Prabang's most popular money-gambling pétanque court. Phuumii, a prolific doser in Luang Prabang, acted frantically for much of the game. He yelled, clapped, and generally displayed a "hot" sociality that was the subject of much joking among audience members. He both evinced a distracted state and produced distraction. Taa, in contrast, talked more quietly for much of the game.

When the transcript below begins, Phuumii has just made a successful shot and offered to bet Taa additional money. Taa does not treat this offer to bet as genuine, but rejects it out of hand with, "Hah [literally "semen"] who you are playing with?" (line 2). He then takes his shot and misses. His miss seems to encourage Phuumii, who now even more enthusiastically offers to bet him.

I have included this example because of the strong contrast between Phuumii's persistent FPPs and Taa's avoidance of contact. The two actors push toward opposite phatic possibilities. Such a stark contrast is not unusual on the court. As Phuumii offers to bet, his body is hyper-animated; he steps forward, envelops the area where Taa will be throwing his pétanque ball and floods Taa with stimuli (a pointed finger, a circling hand, a shouted "hee4!"). As he addresses Taa and invites him to respond, Phuumii's actions are heavy with what we might call pro-contact phaticity. Everything he does seems to be aimed at getting Taa to attend to and engage with him, and thus lose focus on the game. ${ }^{21}$ Taa, in contrast, plays it cool. After initially rejecting Phuumii's offers out of hand, he ignores Phuumii; he does not look 


\begin{tabular}{|c|c|c|c|c|}
\hline LINE & SPKR. & UTTERANCE / TURN & ADDRESSIVITY & COMMENTS \\
\hline 1 & Phuumii & $\begin{array}{l}\text { liin5 khanêên2 qaw3 bòò1 } \\
\text { play point take Q.PLR } \\
\text { "Want to gamble on this round [i.e., } \\
\text { on who gets points this round]?" }\end{array}$ & To Taa & $\begin{array}{l}\text { As he says this, Phuumii walks } \\
\text { toward the other end of court, } \\
\text { Taa steps into the spot from where } \\
\text { he will throw. }\end{array}$ \\
\hline 2 & Taa & $\begin{array}{l}\text { bêên4 tii3 kap2 phaj3 dee4 } \\
\text { semen hit with who FAC.ONRCD } \\
\text { "Hah [literally "semen"], who do you think } \\
\text { you are playing with?" }\end{array}$ & To Phuumii & $\begin{array}{l}\text { Taa lines up to throw at the } \\
\text { pétanque ball. He watches the } \\
\text { ball as he speaks, smiling slightly } \\
\text { toward the end of his utterance. } \\
\text { He does not look at Phuumii. }\end{array}$ \\
\hline 3 & Phuumii & $\begin{array}{l}\text { liin5 khanêên2 bòò1 } \\
\text { play point Q.PLR } \\
\text { "Want to gamble on this round [i.e., } \\
\text { on who gets points this round]?" }\end{array}$ & To Taa & $\begin{array}{l}\text { Phuumii continues walking toward } \\
\text { the other end of court and glances } \\
\text { back at Taa. }\end{array}$ \\
\hline 4 & & [TAKES SHOT] & & $\begin{array}{l}\text { After four second pause, Taa } \\
\text { takes shot; the shot will miss. }\end{array}$ \\
\hline 5 & Phuumii & $\begin{array}{l}\text { liin5 khanêên2 bòò1 Taa } \\
\text { play point Q.PLR Taa } \\
\text { "Want to gamble on this round [i.e., } \\
\text { on who gets points this round], Taa?" }\end{array}$ & To Taa & $\begin{array}{l}\text { Phuumii begins to speak as the } \\
\text { ball is sailing through the air. }\end{array}$ \\
\hline 6 & Taa & $\begin{array}{l}\text { qoo } \\
\text { CRY } \\
\text { "Oh!" }\end{array}$ & Self-addressed & $\begin{array}{l}\text { Taa says this immediately after } \\
\text { his missed shot lands. }\end{array}$ \\
\hline 7 & Phuumii & $\begin{array}{l}\text { liin5 khanêên2 bòò } 1 \text { Taa } \\
\text { play point Q.PLR Taa } \\
\text { "Want to gamble on this round [i.e. } \\
\text { on who gets points this round], Taa?" }\end{array}$ & To Taa & $\begin{array}{l}\text { Phuumii points with } \\
\text { his right hand and oscillates } \\
\text { his hand back and forth, rapidly. } \\
\text { He begins to lean in closer } \\
\text { to the already thrown balls. }\end{array}$ \\
\hline 8 & Phuumii & $\begin{array}{l}\text { tii3 nuaj1 nii4 haa5 daj4 } \\
\text { hit ball DEM five COMP } \\
\text { "If you knock this ball, you will get five [points]." }\end{array}$ & To Taa & $\begin{array}{l}\text { Phuumii leans in closer toward the } \\
\text { already thrown pétanque balls and } \\
\text { points at the target ball. He then } \\
\text { circles his hand around, displaying } \\
\text { from where the "five points" in the } \\
\text { game will come. }\end{array}$ \\
\hline 9 & Phuumii & $\begin{array}{l}\text { hee4 } \\
\text { CRY } \\
\text { "Hah!" }\end{array}$ & To Taa & $\begin{array}{l}\text { Phuumii moves back from the target } \\
\text { ball's area as Taa winds up to take } \\
\text { his shot. }\end{array}$ \\
\hline
\end{tabular}

Figure 2. Dosing with FPPs.

at him, he does not talk to him, but merely bellows out a response cry upon missing a shot (line 6). His actions are loaded with another kind of contact phaticity, namely, an apparent studied disattention to Phuumii's FPPs, along with his offers of information (as in line 8, where he says: "If you knock this ball, you'll get five [points]") and noisiness, (i.e. the non-referentially meaningful cry hee4 in line 9); such disattention is both a tool for ignoring Phuumii and a sign that Taa is unaffected (Zuckerman, Forthcoming).

Offers to bet are said to be potent FPPs. As one player told me during an interview, these offers encourage a potential victim to think about the money he already has staked, and to thus feel more pressure. These offers are thought especially effective if the player entertains the bet, steps back from his shot, and chats for a moment. For example, Phuumii, a few minutes after the talk in the next example (Figure 3), paused before throwing and responded to a series of offers to bet (none of which materialized) from Taa, Laa, and two other audience members. One of the audience members commented about Phuumii's apparent openness to such FPPs when he was about to shoot: "He's just there looking to apply pressure on himself." 22

There are parallels to the phatic violence of the court in a number of different contexts. Haviland (2011:258), citing Sacks and Jefferson (1995), calls the adjacency pair a "basic mechanism of social coercion" and it seems that FPPs are particularly 
good ways of getting one's communicative "foot in the door." Gardner (1980:342) shows that street harassers, in a more troubling variety of phatic violence, use these coercive devices to engage their victims. She provides the following example: "A young woman walks past a New York stoop where she hears a man say sincerely, 'Excuse me, miss.' When she turns to see what he wants, he says, 'You sure have got great boobs.'" Like the street harasser, Phuumii uses first pair parts, in this case bet offers, to grab Taa's attention and suggest he respond.

FPPs like offers to bet are compelling phatic resources in that they, like summonses (Schegloff 1968), project further talk. Unlike Can's scream, or even "You'll overthrow it," they do not open contact (in the form of their victim's attention) merely to then close it, but invite relatively sustained involvement from their victims and encourage a "symmetrical" form of contact, where both actors execute signs for one another and attend to signs from one another.

In the next example (Figure 3), I show that dosers do not just use FPPs as mechanisms to draw potential victims into conversation, but that they sometimes force contact through the use of SPPs (or second pair parts, the expected answers and responses that people provide to FPPs) designed to intercept their victims' talk in what we might label a kind of "SPP-poaching." In this example, taken from the same match, Taa twice asks his partner, Laa, questions. Laa responds to Taa's questions each time, but so does Phuumii. In responding as well, Phuumii tries to "poach" the SPP from Laa. When Taa asks his questions, he is deciding whether he should make a "shooting" shot (in which he would aim to hit a ball off the court) or an "approach" shot (in which he would aim to throw his ball close to the jack). To do this, he needs to know how many remaining balls his partner, Laa, has, and how many remaining balls Phuumii and Phuumii's partner have.

Taa asks three questions during this segment of the interaction (in lines 1, 5, and 9), two of which (lines 1 and 9) are clearly addressed to Laa. Both Laa and Phuumii answer all three of these questions with their own SPPs (as shown in the Adjacency Relation column of Figure 3; parallelistic forms are in grey).

Below, I present each of the three adjacency-pair-sets in detail to show how Phuumii intercepts Taa's FPPs and uses them as a pivot from which to further dose Taa. First, in line (1), Taa addresses Laa, with the question "Are you out of balls?"23 Laa responds to Taa, matching, as is common, the format of Taa's question (that is, he also uses the words mot2 lêêw4). Phuumii also responds to-again paralleling, or "format tying" (Goodwin 1990) Taa's FPP — but unlike Laa, he includes an additional (Luang Prabang specific) epistemic sentence final particle (qoo4) that means something like "of course" or "alright" in sentence final position in English. In fact, Phuumii uses similar epistemic sentence final particles in each of his three attempts to SPP-poach, and it is plausible that such epistemic markers help further insert Phuumii into the interaction and set his hooks, as it were. "Recipient tilted epistemic asymmetry," as Stivers and Rossano (2010) put it, has been argued to be one of the features that encourages a response from an interlocutor, and such asymmetry is the core of what a question is. Perhaps the particle qoo4 here not only signals a "tilted epistemic asymmetry," but marks Phuumii's response as a particularly — on the face of it-informative, and thus engaging, SPP.

Phuumii-with one foot already in the communicative door, as it were-then follows this SPP with a dose (also an FPP) in lines (4) and (6). The second dose (6) is an expansion on the first (4) and they form together a popular kind of dose that I call a "bravery" gambit. In saying, "Are you brave enough to shoot?" Phuumii presupposes some common assumptions about "shooting" shots: they are higher risk and higher reward, and they take a strong, brave, and masculine heart to pull off. The idea behind the bravery gambit is to challenge your opponent's "heart," to force him into a poor decision, but also more generally, to make him overthink whether he is skilled enough or has the mettle to take a shot.

But Taa ostensibly ignores Phuumii's FPPs about bravery, and (in line 5) asks how many balls Phuumii has, information he needs in order to decide whether he should 


\begin{tabular}{|c|c|c|c|c|}
\hline LINE & SPKR. & ADJ. RELATION & ADDRESSIVITY & COMMENTS \\
\hline 1 & Taa & $\begin{array}{l}\text { too3 mot2 lêêw4 vaa3 } \\
\text { 2nd.Sg out PRF Q.PLR } \\
\text { "Are you out of [balls]?" }\end{array}$ & To Laa & $\begin{array}{l}\text { Taa stands near throwing spot. Laa } \\
\text { and Phuumii stand (Phuumii behind } \\
\text { Laa) on the other end of the court. }\end{array}$ \\
\hline 2 & Laa & $\begin{array}{l}\text { mot2 lêêw4 } \\
\text { out PRF } \\
\text { "[I'm] out." }\end{array}$ & To Taa & $\begin{array}{l}\text { Laa looks at Taa and slightly } \\
\text { raises his eyebrows as he responds. }\end{array}$ \\
\hline 3 & Phuumii & $\begin{array}{l}\text { mot2 qoo4 } \\
\text { out FAC } \\
\text { "[He's] out alright!" }\end{array}$ & To Taa & $\begin{array}{l}\text { Phuumii stands, his wrists on his } \\
\text { hips. }\end{array}$ \\
\hline 4 & Phuumii & $\begin{array}{l}\text { kaa } 4 \\
\text { brave } \\
\text { "[Are you] brave [enough]?" }\end{array}$ & To Taa & $\begin{array}{l}\text { Phuumii leans forward slightly on } \\
\text { his left foot as he says this. }\end{array}$ \\
\hline 5 & Taa & $\begin{array}{l}\text { qaaj4 Phuumii ñang2 nuaj1 nùng1 nòq1 FPP (C) } \\
\text { EB Phuumii still ball one Q.PLR } \\
\text { "Older brother Phuumii just } \\
\text { has one ball left, right?" }\end{array}$ & $\begin{array}{l}\text { To Laa or } \\
\text { Phuumii }\end{array}$ & $\begin{array}{l}\text { Taa stands still with his pétanque } \\
\text { displayed in his right hand. }\end{array}$ \\
\hline 6 & Phuumii & $\begin{array}{l}\text { kaa4 tii3 bòò1 } \\
\text { brave hit Q.PLR } \\
\text { "[Are you] brave enough to shoot?" }\end{array}$ & To Taa & $\begin{array}{l}\text { Taa stays still, Phuumii steps } \\
\text { toward back of court. }\end{array}$ \\
\hline 7 & Phuumii & $\begin{array}{l}\text { [ñang2 thêê } 4 \\
\text { still truly } \\
\text { "[l] still have balls left, alright!" }\end{array}$ & To Taa & $\begin{array}{l}\text { Phuumii displays the pétanque ball } \\
\text { he is holding, extending it outward } \\
\text { with his palm upward. }\end{array}$ \\
\hline 8 & Laa & $\begin{array}{l}\text { [ñang2 phuu5 laø-nuaj1 } \\
\text { still person per-ball } \\
\text { "[They] have one ball per person" }\end{array}$ & To Taa & $\begin{array}{l}\text { Laa points toward Phuumii and } \\
\text { Saj, oscillating his index } \\
\text { finger between them. }\end{array}$ \\
\hline 9 & Taa & $\begin{array}{l}\text { phuu5 laø-nuaj1 qaq1 } \\
\text { person per-ball Q.PLR } \\
\text { "[We] have one ball per person?" }\end{array}$ & To Laa & \\
\hline 10 & Laa & $\begin{array}{l}\text { qee3 phuu5 laø-nuaj1 } \\
\text { yeah person per-ball } \\
\text { "Yeah, [they] have one ball per pers }\end{array}$ & To Taa & $\begin{array}{l}\text { Laa nods his head slightly as he says } \\
\text { this. }\end{array}$ \\
\hline 11 & Phuumii & \begin{tabular}{l|l} 
phuu5 laø-nuaj1 naa1 & SPP (E) \\
person per-ball FAC \\
"[We] have one ball per person, alright."
\end{tabular} & To Taa & $\begin{array}{l}\text { Phuumii walks in front of Laa, } \\
\text { toward Taa's right side. Taa steps into } \\
\text { throwing position, raises right arm. }\end{array}$ \\
\hline 12 & Phuumii & $\begin{array}{l}\text { bòø-thùuk5 lêqø-sia3 hok2 leej2 naø-Taa } \\
\text { NEG-hit and-lose six without.ado FAC-Taa } \\
\text { "If [you] miss [the shot] then [you'll] lose six points }\end{array}$ & $\begin{array}{l}\text { To Taa } \\
\text { s, Taa." }\end{array}$ & $\begin{array}{l}\text { Phuumii continues walking. } \\
\text { Taa readies to take his shot. }\end{array}$ \\
\hline
\end{tabular}

Figure 3. SPP-poaching.

"shoot" or "point" on his upcoming turn. Unlike Taa's first FPP (i.e., FPP(A)) the addressivity of this utterance seems more diffuse, at least in the moment it is said; Taa looks at Phuumii as he says it, but it is unclear whether this looking is a sign of addressivity, or a gathering of information about his subject matter (i.e., Phuumii). The form qaaj4 or "older brother" that Taa uses to refer to Phuumii does not tell us much either, as it can be used both as an address term or a third person referent, depending on the context. In response, Phuumii provides Taa with another format tied SPP (line 7), and another attempt at poaching. Here again, he uses an epistemic particle, this time thêe 4 , which often means "true" but which in this context I have translated, like qoo1, as "alright!" Laa, in turn, overlapping in speech with Phuumii (as marked with an initial bracket in the transcript), provides Taa with a more specific SPP (line 8), again format tying his SPP with Taa's FPP. Taa presented with two simultaneous SPPs, one from Laa and one from Phuumi, ignores Phuumii and asks Laa a follow-up question.

SPP-poaching like this highlights a tension at the heart of dosing and gambling, mentioned above. No matter how dangerous to your concentration attending to or 
talking to an opponent might be, when you play pétanque, contact is a necessary part of the game - teams need to be made, turns need to be coordinated, and points need to be counted. Taa's diffusedly addressed question (line 5) seems a partial acknowledgment of this tension: although Phuumii would be more likely to know the answer to the question, as soon as it is clear that Laa, Taa's partner, knows the answer, Taa engages with Laa and not with Phuumii.

Taa's next FPP (line 9; FPP(E)) is also responded to by both Laa and Phuumii, and, once again, Phuumii's response includes a sentence final epistemic particle, naa1, which, as Enfield (2007:43) puts it, marks information that a speaker does not know, but maybe should know. Here Phuumii again uses his SPP as a segue to further dosing, where, in line 12, he untruthfully tells Taa that if he misses his shot he will lose six points - a last minute attempt to get into Taa's ears when, in reality, the game is almost already in Taa's hands.

Throughout this bit of interaction, Phuumii's SPP-poaching sets up a series of antagonistic doses, which Taa continues to ignore. That is, he ignores these doses until just after this transcript ends, when he thereupon takes and makes his shot, and -no longer at risk of losing his focus - says: "fòoj3," a verb meaning to "talk emptily" and in this context, basically, "You're bullshitting." Much dosing is framed like this: bullshitting; a series of nagging questions and responses to be ignored; contact for distraction, for greed, for another's money.

Phuumii was, by all accounts, not successful. Even with his FPPs and SPPs, during this stretch of interaction, he failed to affect Taa in any obvious way, and eventually lost the game. But even as he failed, his methods-his communicative grappling hooks, as it were - exhibit some of the means dosers use to establish contact for purposes other than building good will or forming positive social relations.

When two people are good friends or family in Laos, the often-violated ideological assumption is that they never gamble for money together. Normatively, if one gambles at all, one should gamble only with vague associates. Talk during money games, when people are brave enough to "open their mouths," is thus imagined to be either hyper-polite (as it was described in Vientiane) or "noisy" (nan2) and aggressive. This is the opposite of how talk during "friendly" games is imagined. In such games, especially those where people are playing for beer, distraction is prevalent. But this distraction is said to produce different social effects. Many claim that it is not really dosing as it is done for "fun" (muan1) rather than economic gain. The distraction is described as "joking" (kaan3 jò̀k5) and seems of a piece with other practices where people poke and prod their friends, displaying their friendship through pseudo-antagonism and mock violence. While Bii became seriously angry with Can for screaming at him, during beer gambling games players at times do much worse without reprimand. I have seen a player laugh, for example, as his doser whacked him hard on his backside with a stick during a shot. The contact trope behind such "joking" distraction is similar-as people say that one should try to ignore those talking to you while you are attending to the game- - but the presumed social entailments of contact are different. The difference is economic interest. The joke is a friendly violation, while the "dose" is a sign of greed and an act of unfair play. The joke is talk "for fun," where the dose is talk "for money." 24

\section{What Contact Affords}

In Luang Prabang, Laos, like everywhere else in the world, "contact" is not onedimensional, even when people talk about it as if it were. Contact (whether mediated by a phone call, a WhatsApp message, or a visit to a baby shower or funeral) is at times taken as, in and of itself, a sign of "love" and "solidarity," positive sociality and intimacy. At other times, like those discussed above, contact is shorthand for distraction. But neither the former, more positive contact tropes nor the latter trope embedded in discussions of dosing are pre-semiotic. Instead, contact affords a variety 
of pragmatic effects (Keane 2014:11). Nevertheless, contact does seem an especially productive affordance for people to think through sociality and the meaning of social relationships. This is perhaps because, at its most basic, contact is sociality. Relations between communicative elements are relations, even if the content of such relations is stripped down, ripe for elaboration, as simple as "this is addressed" or "this has been seen."

Simmel (1949:255) wrote, before Malinowski, that "association" with others, in its broadest sense, can, on the one hand, be a "burden, endured for the sake of our objective aims." But it can also, on the other hand, produce its own satisfaction, as "the solitariness of the individual is resolved into togetherness, a union with others." As I trace above, Malinowski's notion of "phatic communion" emphasized the latter phenomenon, where people revel in contact, co-presence, and the sounds of one another's voices. But as the epigraph to this article shows, Malinowski was also clearly aware that contact can be too much, a burden, a distraction. In the title of this article, I have called dosing "phatic violence" not to coin a new cross-cultural contact trope, nor because dosing (unlike, say, some of the more troubling street harassment mentioned above) is especially violent. While in other contexts, sound can inflict pain (Goodman 2012) or even lead to "soul-loss" (Wikan 1989), I never heard pétanque gamblers explicitly say that dosing, as opposed to say shock or surprise generally (cf., Suwanlert 1988), had these sorts of long-term psychophysical consequences. Instead, I have called dosing phatic violence to mark, as plainly as possible, what communicative contact is not: an always-friendly affair.

Sapir (1921:13) wrote that while language is a "dynamo" capable of powering an elevator, it is almost always operated to feed an electric doorbell. Some decades later -as part of a brief discussion of "phatic" and other "conventional" forms-Uriel Weinreich (1963:118) commented that linguists' most pressing task is to explore the elevator, not the doorbell. And yet, "phaticity," the doorbell of language, and of semiotic life more generally, is often a site of preoccupation and elaboration for people themselves, as it is in dosing. It is thus worthy of attention. What might it mean to summon a person to the door, to refuse to answer, or to play ding-dongditch?

\section{Notes}

Acknowledgments. This research was conducted with support from Fulbright Hays, Wenner Gren, and the University of Michigan. Thanks especially to the dosers and non-dosers in Laos who graciously and generously put up with my questioning and mostly tolerated my attempts at dosing. Outside of Laos, many have helped me think through phaticity along the way, especially Jeff Albanese, Kimberly Ang, Meghanne Barker, Nick Enfield, Judith Irvine, Webb Keane, Paul Kockelman, Alaina Lemon, Michael Lempert, John Mathias, Perry Sherouse, an anonymous reviewer, and the editor, Alexandra Jaffe. Versions of this paper were presented at the University of Michigan's Ling Lab, the Michicagoan conference, and the AES spring conference. In each venue, I received incisive comments. Thanks to Michael Silverstein for his discussant-ship at the AES conference, to Aaron Ansell and James Slotta for organizing the panel on "phatic anxieties," and to Sarah Muir, Shunsuke Nozawa, and Becky Schulthies for further discussion.

1. For transcription of the Lao, I follow the system outlined in Enfield (2007). The numbers following syllables represent tonal contours in the Vientiane dialect. I have omitted these tone markers from the term saj1 jaa3 to ease reading.

2. Malinowski adopted the word phatic, as Senft (1995:227) tells us, from the Greek, phatos

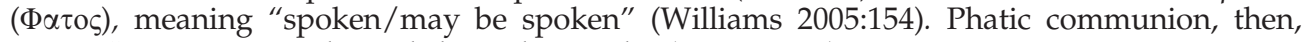
meant "communion achieved through speech" (Laver 1975).

3. An anonymous reviewer notes that "communion" can have a more neutral sense. While this is true, Malinowski was clearly stressing (and has been interpreted as stressing) the broadly "positive" social effects of communication (cf. Senft 1995:227).

4. Thanks to Michael Silverstein for first pointing me toward this quotation.

5. Dell Hymes (1968:121), for example, recognized this disjuncture and suggested dividing the phatic function into two subtypes. 
6. But, while we might sympathize with the cause of this battle, studies of communion phaticity tend to imply a stark dichotomy between the referential and affiliative dimensions of language. (There are, of course, many exceptions: for example, Coupland, Coupland, and Robinson's subtle study of "How are you?" (1992).) These dimensions of language are not always so neatly separated, but often conjoined in the same time, space, and linguistic forms (Rampton 2014:3). Furthermore, because "phatic talk" is from this perspective by definition uninformative talk, these scholars have tended to identify it in the negative, i.e., as forms not demonstrably aimed at communicating "information" and thus, by implication, aimed at producing "social ties." This has sometimes turned the phatic into a residual category of communication without clear function, where if a form doesn't mean anything referentially explicit, or is redundant, or is unimportant, it is liable to be defined as "just phatic." Rampton (2014:3-4) points out the hyperbole of claims that "phatic talk" is meaningless; if someone remarks, for instance, that President Kennedy's inaugural speech carried "little information," "we'd have to believe that the President simply hummed or scatted through the inauguration." (Rampton was referring to a claim made in Leech (1981)).

7. In retrospect, it was probably not the best term to use-perhaps the "engineer" or "operator" function would have been better-but see Jakobson (1971:557) for his negative view of neologisms.

8. Clark follows Austin (1975). See Enfield (2013:91) for elaboration. Confusingly, Austin also uses the term "phatic" in yet another sense, unrelated to Malinowski's.

9. One of contact phaticity's more interesting perforations concerns the distinction between moments where contact is presupposed and taken for granted and those moments where contact is an object of explicit metapragmatic engagement, or reference. Think of the difference between a singer's cooing and a microphone check. Whereas the former presupposes that the microphone and amplificatory system are working, the latter's purpose is to test these devices, foregrounding their possible failure.

10. The status of channel as a count noun also invites people to count channels in interaction, an exercise that can lead to endless line drawing and ad hoc distinctions.

11. Although Jakobson's model is a model of the "speech event," for a number of reasons, any adequate theory of contact phaticity must not limit itself to the spoken. Here, I follow Kockelman (2010:407) in repurposing the model and turning it into a model of "semiotic events of any kind." Limiting ourselves only to spoken language precludes us from taking the materiality of new technologies seriously, and from wondering, for example and following Nozawa (2013), "What, really, is at stake when those 'three dots' flicker 'while the person on the other end of your text message is writing a response."'

12. Of course, so are tunnels. I do not aim to further reify a distinction between the material and the semiotic here, merely to disabuse the notion that channels are found objects.

13. I recorded these games using a pair of mounted digital video cameras (one on each side of the gravel court) and a central Zoom H4N microphone. They form part of a large corpus of both beer and money-gambling games collected during fifteen months of fieldwork in Luang Prabang from 2013-2016.

14. Compare Gardner's (1980:336) discussion of the harassment of women on American streets. When harassers were confronted by harrassees, they too claimed they were "only kidding."

15. After repeated listening, it is clear that Can ended his scream with vaw 4 nang3 or "What did [you] say?," perhaps in reference to the offensive nickname (omitted here to guard Can's identity) that Bii repeatedly called Can. Later, Bii asked Can if he would prefer if he called him "duck shit" instead of the nickname he was using. I have altered the image-a screen grab from one of my video-recordings-to preserve anonymity.

16. tùùn1 thêê4 hòong4 bak2 hêêng2 ( $h$ ) (h) hêêng2 qiø-tùùn1 leej2

17. qee3 qan3 nii4 lêq1 qan3 nii4 nii4 tang4 saj1 jaa3 thêê5 thêê5 dêê1 qan3 nii4 naq1.

18. qan3 nii4 man2 cong3 caj3 thii1 siø-vaw4 saj1 jaa3 phuu4 nii4 thêê5 thêê5

19. mùng1 jaak5 vaw4 laø-vaw4 mot2 mùù leej2 naa1. The fact that Bii made the shot obviously made this a more powerful index of his invulnerability to Can's talk.

20. For further discussion of these local categories of emotional state in a similar context, see Cassaniti (2015).

21. While no one explicitly said that Phuumii was dosing during this or the next segment of talk, Phuumii was accused of dosing - generally-multiple times during the game. On the whole, these examples are relatively uncontroversial, recognizable, and idiomatic "doses" (especially Phuumii's "bravery gambit" and his offers to bet, discussed below), even if Phuumii might have denied that they were anything but "talk."

22. juu1 laa5 laa5 sòok4 khwaam2 kotdan3 saj1 too3 qèng3 
23. Some obvious evidence of addressivity is that Taa uses a second person pronoun, "too3," which would be unusually informal for him to use in relation to Phuumii, whom he addresses with caw4 (a more polite second person pronoun) or qaaj4 Phuumii (i.e., "older-brother Phuumii") throughout other moments of the interaction (Enfield and Stivers 2007).

24. Although I do not have space to walk through examples of this in this article, the line between "talk" and a "dose" is, of course, negotiated, debatable and underdetermined. So too for the lines between "jokes" and serious affronts, friends and enemies.

\section{References}

Ahearn, Laura M.

2011 Living Language: An Introduction to Linguistic Anthropology, Vol. 7. Hoboken, NJ: John Wiley \& Sons.

Austin, John Langshaw

1975 How to Do Things with Words, Vol. 88. Cambridge, MA: Harvard University Press.

Bales, Robert F., Fred L. Strodtbeck, Theodore M. Mills, and Mary E. Roseborough

1951 Channels of Communication in Small Groups. American Sociological Review 16(4):461468.

Bateson, Gregory

1972 A Theory of Play and Fantasy. In Steps to an Ecology of Mind Pp. 177-193. Chicago: University of Chicago Press.

Brenneis, Donald

1988 Language and Disputing. Annual Review of Anthropology 17:221-237.

Buckley, Lindsay

2015 How to Survive the New York City Subway. Matadornetwork.com. http://matadornetwork.com/nights/nyc-subway-survival-guide/.

Cassaniti, Julia

2015 Living Buddhism: Mind, Self, and Emotion in a Thai Community. Ithaca, NY: Cornell University Press.

Clark, Herbert H.

1996 Using Language. New York: Cambridge University Press.

Coupland, Justine, ed.

2014 Small Talk. New York: Routledge.

Coupland, Justine, Nikolas Coupland, and Jeffrey D. Robinson

1992 "How Are You?": Negotiating Phatic Communion. Language in Society 21(2):207-230.

Duranti, Alessandro

1992 Language and Bodies in Social Space: Samoan Ceremonial Greetings. American Anthropologist 94(3):657-691.

1997 Universal and Culture-Specific Properties of Greetings. Journal of Linguistic Anthropology 7(1): 63-97.

Durkheim, Emile

1915 The Elementary Forms of Religious Life. New York: The Free Press.

Elyachar, Julia

2010 Phatic Labor, Infrastructure, and the Question of Empowerment in Cairo. American Ethnologist 37(3):452-464.

Enfield, Nick J.

2007 A Grammar of Lao. Berlin and New York: Mouton.

2013 Relationship Thinking: Agency, Enchrony, and Human Sociality. New York: Oxford University Press.

Enfield, Nick J., and Tanya Stivers, eds.

2007 Person Reference in Interaction: Linguistic, Cultural, and Social Perspectives. Cambridge, UK: Cambridge University Press.

Firth, John Rupert

1957 Ethnographic Analysis and Language with Reference to Malinowski's Views. Man and Culture: An Evaluation of the Work of Bronislaw Malinowski: 93-118.

Fleming, Luke, and Michael Lempert

2014 Poetics and Performativity. Cambridge Handbook of Linguistic Anthropology: 469495.

Gardner, Carol Brooks

1980 Passing By: Street Remarks, Address Rights, and the Urban Female. Sociological Inquiry 50(3-4): 328-356. 
Geertz, Clifford

1973 Deep Play: Notes on a Balinese Cockfight. In The Interpretation of Cultures. Pp. 412 453. New York: Basic Books.

Geoghegan, Bernard Dionysius

2011 From Information Theory to French Theory: Jakobson, Levi-Strauss, and the Cybernetic Apparatus. Critical Inquiry 38(1):96-126.

Goodman, Steve

2012 Sonic Warfare: Sound, Affect, and the Ecology of Fear. Cambridge, MA: MIT Press.

Goodwin, Charles

1981 Conversational Organization: Interaction between Speakers and Hearers. New York: Academic Press.

Goodwin, Marjorie

1990 He-Said-She-Said: Talk as Social Organization among Black Children. Bloomington and Indianapolis: Indiana University Press.

Haviland, John B.

2011 Who Asked You, Condom Head? Anthropological Quarterly 84(1):235-264.

Hayakawa, Samuel Ichiyé

1941 Language in Action. New York: Harcourt, Brace.

Hymes, Dell H.

1968 The Ethnography of Speaking. In Readings in the Sociology of Language. Joshua A. Fishman, ed. Pp. 99-138. The Hague, the Netherlands: Mouton.

Irvine, Judith $\mathrm{T}$.

1996 Editorial: Language and Community: Introduction. Journal of Linguistic Anthropology 6(2): 123-125.

Jakobson, Roman

1960 Closing Statement: Linguistics and Poetics. In Style in Language. T. Sebeok, ed. Cambridge, MA: MIT Press.

1961 Linguistic and Communications Theory. Providence, RI: American Mathematical Society.

1971 Selected Writings. 2.Word and Language. The Hague, the Netherlands: Mouton de Gruyter.

Keane, Webb

2014 Affordances and Reflexivity in Ethical Life: An Ethnographic Stance. Anthropological Theory 14(1):3-26.

Kockelman, Paul

2010 Enemies, Parasites, and Noise: How to Take Up Residence in a System without Becoming a Term in It. Journal of Linguistic Anthropology 20(2):406-421.

Laver, John

1975 Communicative Functions of Phatic Communion. In Organization of Behavior in Faceto-Face Interaction. Adam Kendon, Richard M. Harris, and Mary Ritchie Key, eds. Pp. 215-238. The Hague, the Netherlands: Mouton.

Leech, Geoffrey

1981 Semantics: The Study of Meaning. Harmondsworth, UK: Penguin Books.

Lemon, Alaina

2013 Touching the Gap: Social Qualia and Cold War Contact. Anthropological Theory 13(1-2): 67-88.

Lempert, Michael

2012 Indirectness. In The Handbook of Intercultural Discourse and Communication. Christina Bratt Paulston, Scott F. Kiesling, and Elizabeth S. Rangel, eds. Pp. 180-204. Malden, MA: Wiley-Blackwell.

Malinowski, Bronislaw

1965 Coral Gardens and Their Magic, Vol. 2: The Language of Magic and Gardening. Bloomington: Indiana University Press.

1967 A Diary in the Strict Sense of the Term. Norbert Guterman, trans. London: Routeledge \& Kegan Paul.

Manning, Paul

2008 Barista Rants about Stupid Customers at Starbucks: What Imaginary Conversations Can Teach Us about Real Ones. Language \& Communication 28:101-126. 
Meltzer, Bernard N., and Gil Richard Musolf

2003 Phatic Communion: Bringing Unfocused Interaction into Focus. In Structure \& Agency in Everyday Life. Gil Richard Musolf, ed. Pp. 141-154. Lanham, MD: Rowman \& Littlefield.

Nozawa, Shunsuke

2013 Contact and Its Allure: Using Phaticity to Explore Social Relations, Technology, and More. Anthropology News.

2015 Phatic Traces: Sociality in Contemporary Japan. Anthropological Quarterly 88(2):373400.

Ogden, Charles Kay, Ivor Armstrong Richards, Bronislaw Malinowski, and Francis Graham Crookshank

1946 The Meaning of Meaning. New York: Harcourt, Brace \& World.

Pagliai, Valentina

2010 Introduction: Performing Disputes. Journal of Linguistic Anthropology 20(1):63-71.

Quealy, Kevin, and Justin Wolfers

2015 Free-Throw Distraction: The Best Fans in the N.C.A.A. New York Times, March 12. http:/ / www.nytimes.com/2015/03/13/upshot/free-throw-distraction-the-best-fans-inthe-ncaa.html?abt=0002\&abg=1.

Rampton, B.

2014 Conviviality and Phatic Communication. Working Papers in Urban Language \& Literacies 140.

Sacks, Harvey, and Gail Jefferson

1995 Lectures on Conversation 2.

Saft, Scott

2007 Exploring Aizuchi as Resources in Japanese Social Interaction: The Case of a Political Discussion Program. Journal of Pragmatics 39(7):1290-1312.

Sapir, Edward

1921 Language: An Introduction to the Study of Speech. New York: Harcourt, Brace.

1949 Selected Writings of Edward Sapir in Language, Culture and Personality. Berkeley: University of California Press.

Schegloff, Emanuel A.

1968 Sequencing in Conversational Openings. American Anthropologist 70(6):1075-1095.

1998 Body Torque. Social Research 65(3): 535-596.

Schneider, Klaus P.

1988 Small Talk: Analyzing Phatic Discourse, Vol. 1. Marburg, Germany: Hitzeroth.

Senft, Gunter

1995 Phatic Communion. In Handbook of Pragmatics. Jef Verschueren, Jan-Ola Östman, Jan

Blommaert, and Chris Bulcaen, eds. Pp. 1-10. Amsterdam: John Benjamins.

Shannon, Claude E., and Warren Weaver

1998 The Mathematical Theory of Communication. Urbana: University of Illinois Press.

Sidnell, Jack

2009 Participation. The Pragmatics of Interaction 4:125-156.

Silverstein, Michael

1976 Shifters, Linguistic Categories, and Cultural Description. In Meaning in Anthropology.

Keith H. Basso and H. A. Selby, eds. Pp. 11-56. Sante Fe, NM: University of New Mexico Press.

2003 Indexical Order and the Dialectics of Sociolinguistic Life. Language \& Communication 23: 193-229.

Simmel, Georg, and Everett C. Hughes

1949 The Sociology of Sociability. American Journal of Sociology 55(3): 254-261.

Slotta, James

2015 Phatic Rituals of the Liberal Democratic Polity: Hearing Voices in the Hearings of the Royal Commission on Aboriginal Peoples. Comparative Studies in Society and History 57(1):130-160.

Stivers, Tanya, and Federico Rossano

2010 Mobilizing Response. Research on Language and Social Interaction 43(1):3-31.

Suwanlert, Sangun

1988 A Study of Latah in Thailand. Journal of the Psychiatric Association of Thailand 33(3):129-133.

Trudgill, Peter

2003 A Glossary of Sociolinguistics. New York: Oxford University Press. 
Virilio, Paul

1994 The Vision Machine. Bloomington: Indiana University Press.

Wang, Victoria, John V. Tucker, and Kevin Haines

2012 Phatic Technologies in Modern Society. Technology in Society 34(1):84-93.

Wang, Victoria, John V. Tucker, and Tracey E. Rihll

2011 On Phatic Technologies for Creating and Maintaining Human Relationships. Technology in Society 33(1):44-51.

Weinreich, Uriel

1963 On the Semantic Structure of Language. Universals of Language 1:142-215.

Wikan, Unni

1989 Illness from Fright or Soul Loss: A North Balinese Culture-Bound Syndrome? Culture, Medicine and Psychiatry 13(1):25-50.

Williams, Tim

2005 A Dictionary of the Roots and Combining Forms of Scientific Words. Fakenham, UK: Squirrox Press.

Young, Michael W.

2012 Malinowski's Last Word on the Anthropological Approach to Language. Pragmatics 21(1):1-22.

Zuckerman, Charles H. P.

2017 Disrupting Agents, Distributing Agency. In Distributed Agency. Nick Enfield and Paul Kockelman, eds. New York: Oxford University Press. 